\title{
Peach rootstock propagation under intermittent mist system
}

\author{
Newton Alex Mayer ${ }^{1}$, Gregory L. Reighard ${ }^{2}$, William Bridges ${ }^{2}$ \\ ${ }^{1}$ Embrapa Clima Temperado, BR 392, km 78, Caixa Postal 403, CEP 96010-971, Pelotas-RS, \\ Brazil.alex.mayer@embrapa.br \\ ${ }^{2}$ Clemson University, Department of Horticulture, 161 Poole Ag. Center, BOX 340310, Clemson, \\ SC 29634,USA. grghrd@clemson.edu; Department of Mathematical Sciences, 117 Martin, \\ Clemson, SC 29634, USA.wbrdgs@clemson.edu
}

Many Prunus spp. genotypes has been studied as rootstocks for stone fruits but there is limited information about clonal propagation by herbaceous and semi-hardwood cuttings. Two trials were conducted under a mist system with temperature and air relative humidity controls. Cuttings (12-cm long, 6-12 $\mathrm{mm}$ in diameter) with entire leaves attached on the distal $2 / 3$ section were prepared and placed in bottom perforated, plastic boxes $(53 \times 26 \times 6.5 \mathrm{~cm})$ filled with course vermiculite. The first trial was done with herbaceous cuttings (June-July, 2011) in a completely randomized $3 \times 3 \times 2$ factorial design [rootstock: 'Krymsk ${ }^{\circledR}$ 86', Lovell and Prunus americana; indole-3-butiric acid (IBA) concentrations: 0, 3,000 and 6,000 ppm; and IBA sources: IBA and IBA-K salt]. Semihardwood cuttings (August-October, 2011) were used for the second trial, which was a completely randomized $3 \times 3$ factorial design (rootstock: Guardian ${ }^{\circledR}$, 'Krymsk ${ }^{\circledR}$ 86' and P. munsoniana; and IBA concentrations: $0,3,000$ and $6,000 \mathrm{ppm}$ ). After 50 days under intermittent mist, there were significant differences among genotypes for all variables related to rooted cutting percentage, root quality, and new shoot formation, with the best results for 'Krymsk ${ }^{\circledR} 86$ '. This genotype was easily propagated even without IBA $(100 \%$ and $98.6 \%$ of rooted cuttings for herbaceous and semihardwood types, respectively). Vegetative buds of Guardian ${ }^{\circledR}$ and Lovell (both P. persica) cuttings did not break during the rooting period. An unique effect of the IBA-K salt was to decrease root dry mass. We conclude that IBA at 3,000 ppm was the best concentration for these genotypes.

Corresponding Author: Newton Alex Mayer, alex.mayer@embrapa.br 